Nota de Leitura 


\title{
Teologia da libertação: história crítica de um discurso intelectual-religioso
}

\author{
VALÉRIO, Mairon Escorsi. O continente pobre e católico: o discurso \\ da teologia da libertação e a reinvenção religiosa da América \\ Latina. Doutorado em História. Campinas, SP, Instituto de \\ Filosofia e Ciências Humanas, UNICAMP, 2012.
}

\author{
Antonio Paulo Benatte*
}

Mairon Escorsi Valério defendeu no Departamento de História da UNICAMP uma instigante tese sobre a teologia da libertação, intitulada 0 continente pobre e católico: o discurso da teologia da libertação e a reinvenção religiosa da América Latina. Trata-se de um trabalho denso e de fôlego sobre um conjunto de enunciados político-religiosos bastante complexos. Inicialmente, é preciso reconhecer a coragem do historiador em enfrentar um tema polêmico e ideologizado em torno do qual já correu muita tinta. É uma aventura perigosa, pois o estudioso corre o risco de tornar-se refém dos enunciados constitutivos do objeto, ou então assumir acriticamente uma ou outra posição ideológica interna ou externa ao campo discursivo. Felizmente, não é esse o caso. Mediante um ecletismo teórico bem temperado, a história cultural desarticula os discursos e narrativas constituintes desse saber, evidenciando suas relações com um projeto político-pastoral em escala continental. Nesse percurso, Valério realiza a proeza de distanciar-se, simultaneamente, tanto da literatura militante como dos discursos contramilitantes, conservadores ou neoconservadores, dos adversários do movimento. Não se trata de afirmar uma impossível objetividade ou neutralidade científica, mas de desprender-se para situá-la historicamente no campo discursivo de uma série de análises por demais coladas às categorias da literatura militante do próprio movimento intelectual-religioso. A operação historiográfica distancia-se assim do olhar das fontes: o discurso teológico que impregna mesmo os estudos "científicos", acadêmicos, nas áreas da teologia, das ciências sociais, da história e das ciências da religião.

"Doutor em História (UNICAMP). Professor do Departamento de História e do Programa de Pós-Graduação em História da Universidade Estadual de Ponta Grossa. E-mail: apbenatti@ibest.com.br 
O distanciamento permite apreender o discurso enquanto acontecimento e prática, evidenciando "uma lógica inerente de saber-poder" que estrutura o discurso teológico. Daí a sensação de que o texto percorre um fio de navalha, relativizando as ideias aceitas sobre a teologia da libertação, mas sem descambar para a polêmica ideológica. Em vez disso, o historiador traça um percurso mais sutil de historicização do campo intelectual e religioso, da trajetória de seus principais atores, do lugar institucional de onde falam, de suas redes de sociabilidade, de suas variadas matrizes de pensamento, das diferentes correntes internas ao paradigma, de seu projeto de saber/poder, em suma, das circunstâncias internas e externas ao discurso, e que determinam suas mutações e permanências na duração. Ao longo do texto, o que emerge são as aporias, contradições, ambiguidades e paradoxos do discurso.

O historiador expõe em poucas linhas a tese de que a teologia da libertação "é antes de qualquer coisa um movimento intelectual, transnacional, levado a cabo por intelectuais religiosos ligados predominantemente à Igreja Católica na América Latina e sua instâncias de poder institucional." (p. 296) O texto historiciza as narrativas e metanarrativas, inclusive a historiográfica, da teologia da libertação sobre si mesma. Ao invés de um "amplo movimento social", como a define seus praticantes e teóricos, o estudo mostra claramente como essa teologia da praxis surgiu na alta hierarquia católica, como teologia oficial da CELAM (Conferência Episcopal Latino Americana) e somente a posteriori buscou-se dar-lhe uma legitimidade a partir das "bases".

Valendo-se de um método prosopográfico (de biografias coletivas), Valério descreve a origem e a trajetória dos principais atores intelectuais do campo; desconstrói o discurso da "Igreja popular", organizada de baixo para cima, mostrando as origens intelectuais e, mais que isso, institucionais da teologia da libertação. A "retórica popular e basista" do discurso não resiste à análise historiográfica. Mesmo a abertura aos leigos pressupunha uma participação popular tutelada por bispos, padres e teólogos. Salta à vista uma "desigualdade simbólica" entre as bases e as figuras centrais do movimento. Esse desnível simbólico aparece inclusive no panteão de mártires do movimento e na própria história e memória heroicizadas pelas narrativas, que privilegiam o clero católico em detrimento do laicato e os intelectuais em detrimento das chamadas "pessoas comuns".

Tem-se, por exemplo, uma literatura quase hagiográfica, apologética e heroicizante dos "bispos-profetas". A análise desmonta assim a autoimagem do distanciamento do mundo clerical construído pela literatura militante, ao mesmo tempo em que mostra as aporias do discurso em sintonia 
com as contradições da prática. $\mathrm{O}$ autor complexifica o campo, dando maior peso ao papel dos intelectuais "orgânicos" na configuração do movimento e evidenciando as relações de poder internas (ou institucionais) e externas (ou contextuais) ao campo católico. Nos anos 1970, a resistência institucional à teologia da libertação fez com que ela emigrasse para um campo híbrido, num espaço de liminaridade entre a igreja e a academia.

Em geral os intelectuais-religiosos identificados com o movimento buscavam a produção de uma teologia latino-americana, transnacional, adequada às especificidades do continente. Para tanto, investiu-se na construção de um espaço imaginário, na invenção de uma identidade comum latino-americana, uma grande "comunidade imaginada" como uma espécie de "entidade simbólica supranacional". Para apreender essas representações, o historiador amplia a noção de "comunidade imaginada", de Benedict Anderson, aplicando-a a todo o continente latino-americano. Nesse trabalho de legitimação, os usos do passado, da memória e da história assumiram uma importância fundamental para a produção de uma teologia continental. 0 resultado é a produção discursiva de uma identidade, a do "continente pobre e católico", a busca de uma memória e de uma história capaz de legitimar, em uma sociedade cada vez mais complexa, plural e heterogênea, o projeto de poder pastoral católico. Valério mostra como a teologia da libertação "reinventou a América Latina e a identidade latino-americana" em consonância com esse projeto institucional. Tratava-se não apenas de buscar a hegemonia no pensamento e na estrutura do catolicismo latino-americano, como também "sua ramificação para o campo não religioso."

O resultado é uma história bastante relativizadora das próprias análises (re) correntes sobre o movimento intelectual-religioso. 0 objetivo último dessa relativização do discurso da teologia da libertação sobre si própria é bastante claro: trata-se de complexificar a dinâmica das relações de saber-poder constitutivas do campo. Esse objetivo é plenamente alcançado pelo estudo. Apesar da não identificação com o contradiscurso conservador dos adversários dessa corrente teológica, o historiador não deixa de fazer afirmações bastante cáusticas, como quando retoma a crítica do teólogo Gustavo Gutiérrez a Tzvetan Todorov, o autor do clássico A conquista da América: a questão do outro. Valério conclui com uma comparação incisiva e bastante crítica de todo o projeto político-pastoral dessa teologia da praxis: "Talvez a constatação de Todorov de que Las Casas amava os índios, mas não os conhecia, tenha se refletido no âmago do que foi a pastoral da teologia da libertação: amava os pobres, mas não os conhecia." (p. 253). E isso talvez devido à 
contradição maior que perpassa o discurso teológico: "Os teólogos da libertação agiam como intelectuais orgânicos, porém não no sentido de defender os interesses das classes populares como seu próprio discurso propugnava, mas no sentido de reforçar a instituição a qual estavam umbilicalmente ligados." (p. 204).

Em suma, a tese mostra como a teologia da libertação operou uma releitura dos próprios movimentos da esquerda católica, dobrando-os à nova lógica de um discurso instituinte e autolegitimador. Esse discurso construiu e veiculou a visão essencialista de um "substrato cultural católico" comum a toda a diversidade latino-americana. Trata-se, desse ponto de vista, de uma teologia etnocêntrica e pouco relativista, apesar da compaixão para com os explorados e oprimidos; um pensamento que buscou se afirmar como único - ou melhor, que aceitou a diversidade, mas para reduzi-la a uma unidade projetada simultaneamente no passado (como mito), no presente (como praxis) e no futuro (como utopia).

Resenha recebida para publicação em 10/08/2013

Resenha aprovada para publicação em 26/11/2013 